\title{
Assessment and compare of determinants of the health status of the elderly referred to health centers in Isfahan
}

\author{
Molavi $\mathrm{R}^{1}$, Alavi $\mathrm{M}^{*^{2}}$, Keshvari $\mathrm{M}^{3}$
}

\begin{abstract}
Introduction and purpose: Monitoring elderly health status to identify risky population is of particular importance in preventing chronic diseases and disabilities. Assessing elderly health status has been considered as one of the most important priorities and challenges in the health care system. Therefore, this study aimed to assess and compare health determinants among elderly attending to health centers of Isfahan city.
\end{abstract}

Materials and methods: This correlation study used stratified random sampling method to recruit 240 elderly (aged above 65 years old) who seek routine health care at 11 health centers in the Isfahan city. Data were collected using socio-demographic questionnaire, Rosenberg's self-esteem scale and Goldberg's general health questionnaires. Data were analyzed using SPSS (Version 19) through variety of statistical test including Pearson correlation, multiple regression analysis, analysis of variance (ANOVA) and independent sample t-test. Ethical considerations were met in the present study.

Findings: Finding from this study revealed that $45.4 \%$ (109) of our participants were male and $54.6 \%$ (131) were female with mean age of $68.4(\mathrm{SD}=4)$ years old. The results of one way ANOVA indicated that participants' health status was significantly differ according to their marital status, occupation and income. Moreover, we found that two variables of self-esteem $(\beta=0.151, t=2.5$, $p=0.013)$ and hospitalization $(\beta=-0.4, t=6.7, p<0.001)$ significantly predicted elderly health status.

Conclusion: Elderly general health status might be promoted via enhancing their mental health status particularly in terms of self-esteem and reducing hospitalization. Therefore, it is beneficial to conduct future studies for assessing role of health determinants among elderly in a broader population.

Key words: Self-esteem, Health, Aging

Received: 2016/05/25

Accepted: 2016/08/31

Copyright () 2018 Quarterly Journal of Geriatric Nursing.This is an open-access article distributed under the terms of the Creative Commons Attribution international 4.0 International License(http://creativecommons.org/licenses/by /4.0/) which permits copy and redistribute the material, in any medium or format, provided the original work is properly cited.

1- MSc in elderly Nursing, University of Medical Sciences, Isfahan, Iran,

2- Assistant Professor, Nursing and Midwifery Care Research Center, Faculty of Nursing and Midwifery, Isfahan University of Medical Sciences, Isfahan, Iran

(Corresponding Author):E-mail: m-alavi@nm.mui.ac.ir

3- Assistant Professor Nursing and Midwifery Care Research Center, Faculty of Nursing and Midwifery, Isfahan University of Medical Sciences, Isfahan, Iran 


\section{بررسى و مقايسه تعبين كننده هاى وضعيت سلامت درسالمندان مراجعه كننده به مراكز سلامت شهر اصفهان}

راضيه مولوى'، موسى علوى" '، ماهرخ كثورى

تاريخ دريافت مقاله: ه/ / / هوسا تاريخ קذيرش مقاله: • / / م/ هوسا

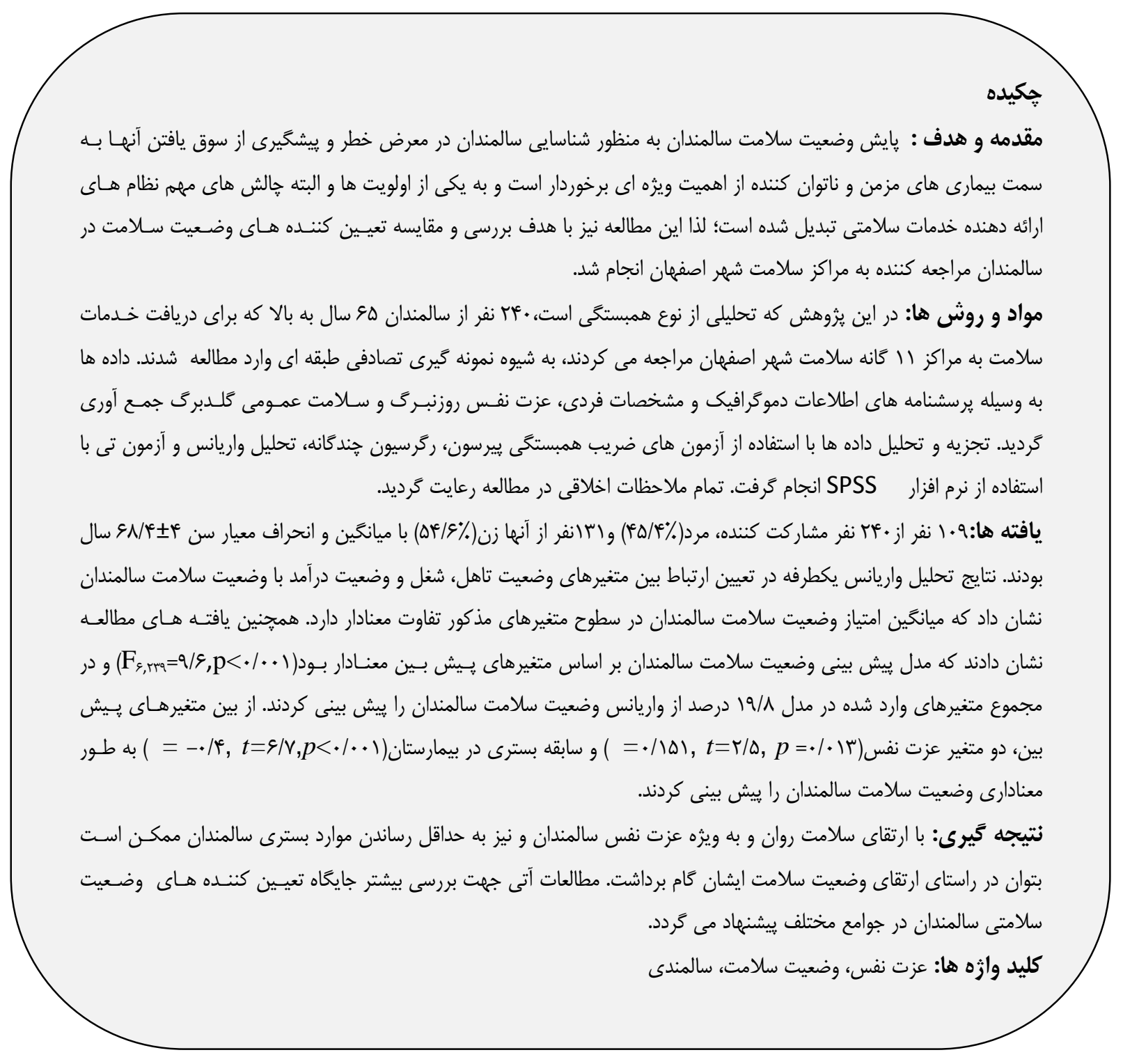

1 - - كارشناس ارشد يرستارى سالمندى، دانشكاه علوم يزشكى اصفهان، اصفهان، ايران

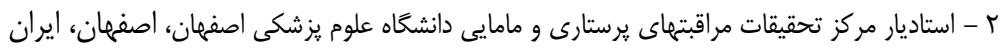

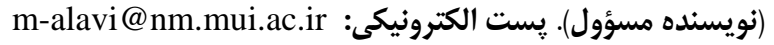
r - استاديار مركز تحقيقات مراقبتهاى يرستارى و مامايى دانشكاه علوم يزشكى اصفهان، اصفهان، ايران 
مقدمه

دوران سالمندى همراه مى باشد(أ()؛ به عنوان مثال يزوهش ها و آمارها نشان مى دهند كه حدود • 1- ب/\% سالمندان اختلالات شناختى و كاهش حافظه را تجربه مى كنند(ه()، هشتاد درصـد بيماران بسـترى بـا نارسـايى قلبـى را سـالمندان تشـكيل مـى دهند(1)، بسترى شدن و مراقبت طولانى مدت به دليـل ابـتلا به عفونت مجارى ادرارى و تنفسى در ايـن خـروه سـنى بيشـتر بوده(ع) و آنها در خطر جلى بسترى شدن و مـرگ در نتيجـهـ عفونتهاى آنفولانزايى هستند(IV). ساير مطالعات نيـز حـاكى از بروز اختلالات حركتى مكرر(1)، آمار بيشتر بسـترى شـدن در فصول سرد سال نسبت به جمعيت هاى ديخــر(19) و نيـز بـروز بيشتر مشكلات ناتوان كنتده همانـــــــاهش شـنوايى در بـين سالمندان مى باشند كه نهايتا" آنها را به سوى اختلال عملكـرد فيزيكى و اجتماعى سوق مى دهند(· ا)؛ از اينرو تامين و ارتقاى سلامت سالمندان به يكى از اولويت ها و البته خالش هاى مهرم نظام هاى ارائه دهنده خدمات سلامتى تبديل شده است. حالش هاى مرتبط با وضعيت سلامت سـالمندان، لـزوم برنامـهـ ريزى هاى آتى براى كنتـرل مسـائل مربـوط بـهـ ايـن خـروه از جمعيت را مورد تاكيد قرار مى دهد و پـايش وضـعيت سـلامت سـالمندان بـهـ منظـور شناسـايى سـالمندان در معـرض خطـر و ييشخَيرى از سوق يافتن آنها به سـمت بيمـارى هـاى مـزمن و ناتوان كننده از اهميت ويزه اى برخوردار است؛ همجنين با توجه به افزايش جمعيت سالمندان و مطرح بودن نيازهاى خاص آنـان و تعاريف سلامتى، لازم است اندازه گيــرى سـلامت و ارزيـابى مداخلات بهداشتى تنها بـهـ شـاخص هـاى تغييـر در فراوانسى و شدت بيمارى محدود نبوده؛ بلكه وضعيت سلامت سالمندان بــه طور كامل مورد توجه قرار گيرد(I).
جمعيت رو به رشد سالمندان و ييامــدهاى ناشـى از آن يكـى از مسائل عمده جمعيتى است كه كشورهاى جهـان اخيـرا" بـا آن

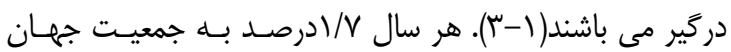
افزوده مى شود؛ ولى اين افزايش براى جمعيت هو سال و بالاتر

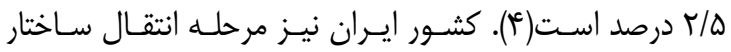
جمعيتى از جوانى به سالخوردگى را تجربه مى كنـد(ه, )؛؛ ايـن افزايش جشمخَير سالمندان در r دها بعد، يكى از جـالش هـاى اصلى براى سيستم مراقبـت بهداشـتى مـى باشـد(V, ^). ياسـخ جوامع مختلف به يديده جهانى رشد جمعيـت سـالمندى مطـرح شدن و تاكيد بر مفهوم "سالمندى يويا " اســ؛ كـه ضـمن آن

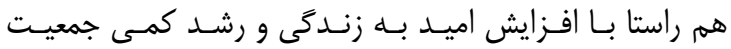
سالمندان، به ابعاد كيفى زندگى ايشان نيز توجه بـيش از يـيش معطـوف شــده اسـت(9) و امـروزه تــامين و ارتقـاى سـلامتى سالمندان، به عنوان يكى از مصاديق مهمم سالمندى يويا شناخته شده است. سازمان جهانى بهداشت در سال 1941 تعريف سلامتى را مبنى بر ابعاد وسيع آن به شكل رفاه كامل جسمانى، روحى، اجتمـاعى و نه فقط عدم وجود بيمارى يا ناتوانى مى داند(·(). اين تعريف، بعدها تحت جهار حيطـه فيزيكىى، ذهنى، اجتمـاعى و معنـوى توصيف شد تا به انسان به عنوان يك كل و يك موجود منسجم

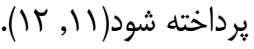
گر جه سالمندى با بيمارى و ناتوانى هم معنى نمسى باشـد؛ امـا سالمندان نسبت به گروههاى سنى جوان تر و به دلايل متعددى در معرض خطر كاهش سلامتى و بيمارى ها و عوارض آنهـا و مرى و مير قرار دارند(سا) و فرآيندهاى زيادى از جمله كـاهش توان جسمى و ذهنى، بروز بيماريهاى مزمن و مشكلات ديگر با 
مد نظر قرار نداده اند. نتايج يراكنده و متناقض موجود در رابطـهـ با نقش ييش بينى كننده متغيرهاى مختلف زمينـه اى و فـردى ضرورت انجام مطالعات بيشتر در اين زمينه را مطرح مى نمايسـ؛ لذا هدف از مطالعه حاضر بررسى نقش ييش بينى كننده برخى از مهمترين متغيرهـاى زمينـهـ اى و فـردى در تعيـين وضـعيت سلامت سالمندان مراجعه كننده به مراكز سلامت شهر اصفهان

$$
\text { مى باشد. }
$$

\section{مواد و روش ها}

اين يزوهش تحليلـى از نـوع همبسـتخى اسـت. جمعيـت مـورد

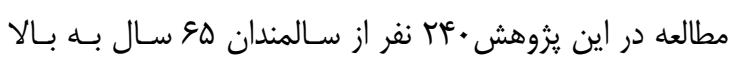
بودند كه به Iا مركـز سـلامت شهر اصـفهان در سـال rوسا جهت دريافت خـدمات سـلامت مراجعـه مـى كردنـد و يرونسـه بهداشتى از ا سال قبل در اين مراكز داشتند و به شـيوه نمونـهـ كيرى تصادفى طبقه اى و با استفاده از جدول اعداد تصـادفى از هر مركز به نسبت تعداد سالمندان تحت يوشش انتخاب شدند. ابزار گَردآورى داده ها در اين يزوهش اطلاعـات دموگرافيـك و مشخصات فردى بود؛ همجنين جهت اندازه گيرى عـزت نفس معيار عزت نفس روزنبرى كه يك مقياس استاندارد مسى باشـد، استفاده شد. اين مقياس در بركيرنده • ا جملـه يـاـ عبـارت مسى باشد و براى سنجش خود ارزشمندى و نخَرش فـرد نسـبت بـهـ خود و احساس واقعى افراد درباره هر يك از جمـلات در طيـف ليكـرت جهــار ززينــه اى(كـاملا"موافـق - موافـقـ- مخــالفكاملا" مخالف) با علامت ضربدر در مقابل هر جمله با نمرات الى ع مشخص شد و نمره كل از مجموع نمرات داده شده براى هر • ا سوال بدست آمـد. بــه ايـن ترتيـب حـداقل نمـره • ا و حداكثر • أ مى باشد كه نمره بالاتر بيانگر ميزان عزت نفس بالا در سالمندان است؛ همجِنين ابـزار انـدازه گيـــى ابعـاد سـلامت
وضعيت سلامت سالمندان از عوامل متعددى منشاء مسى گيرنـــ. برخى از يثروهشَّران درصدد شناسايى اين عوامل تعيين كنــده برآمده اند؛ به عنوان مثال كل يرور و همكـاران در سـال •وسا مطالعـه اى بــا عنـوان رابطــه تركيبـى مولفـهـ هــاى نشـانغان بازنشسـتخان بـا نشـانه هـاى ســامت عمـومى در سـالمندان

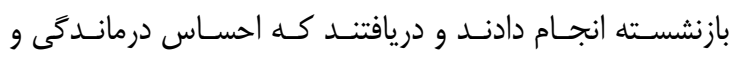
شكست و احساس جهت گيرى و تـلاش جديــد در همـــ ابعـاد سلامت و احساس ييرى و بطالت در ابعاد اضطراب و نشانه هاى جسمانى توان يِشبين دارند(r/)؛ همجنين علييور و همكاران در سال 1Mسا مطالعه اى با عنوان نقش حمايت هاى اجتماعى بـر كاهش اضطراب و افسردگى سالمندان انجام دادنـد، نتــايج ايـنـ مطالعه بر نقش مهرم عوامل اجتماعى تعيين كنتـده سـلامت بــه ويزه حمايت هاى اجتمـاعى در اخـتلالات روانسى در سـالمندان تاكيد دارد(آr). حيدرى و همكـاران در سـال •وسا در مطالعـه خود با عنوان بررسـى وضـعيت سـلامت سـالمندان شـهر قـم، دريافتند كه كيفيت زندگى مرتبط با سلامت با متغيرهـاى سـن، تاهل، تحصيلات، وضعيت اقتصادى، منبع درآمد، نحوه زنـدگى، اشتغال مردان و ابتلا به بيمارى مزمن ارتباط معنى دار دارد(سT). همجنين نجفى و همكاران در سـال بوسا در مطالعـه خــود بــا عنوان وضعيت روانى سالمندان و عوامل مرتبط با آن، به نتيجـهـ رسيدند كه با افزايش هر سال سن، T/9 درصد شـانس مشـكل سـلامت روان افـزايش مـى يابـــ همرِـــين افـزايش سـطح تحصيلات وضعيت سلامت روان را ارتقا مى دهد(بآ). با اينكه هر يك از مطالعات موجود نقش عوامل مختلفى را بــه طور يراكنده در تعيين وضعيت سلامت سالمندان مورد توجه قرار داده اند؛ هيج كدام از آنها جايگاه متغيرهاى مختلف زمينـه ایى و فردى را به صورت يك مجموعه عوامل و در مقايسه با يكديخر 
مستقل) انجام شـــ در تحليـل ركر سـيون، سـن، تعـداد فرزنـــ، زندگى در سراى سالمندان، بسترى شدن در بيمارستان، ابتلا به بيمارى مزمن و عزت نفس به عنـوان متغيرهـاى يـيش بـين و وضعيت سلامت سالمندان نيز به عنوان متغير ملاكى وارد مـدل شدند. در اين مطالعه كليه ملاحظات اخلاقى از جمله داوطلبانـهـ بودن شركت در مطالعه و نيز محرمانه بودن اطلاعات مربوط به شركت كنندكان رعايت شده است.

\section{يافته ها}

در مجموع +^r نفر وارد مطالعه شدند. جدول (1) توزيع فراوانى و نيز ميانكَين و انحر اف معيار ويزَى هـاى فـردى و زمينـه اى مربوط به افراد شركت كننده در مطالعه را نشان مى دهد. به منظور تعيين رابطه جنيست بـا وضـعيت سـلامت سـالمندان شركت كننده در مطالعـه، از آزمـون t در نمونسه هـاى مسـتقل استفاده شد. همجنان كه در جـدول شـماره (Y) ملاحظـهـ مسى رك كَردد، ميانكَين وضعيت سلامت سالمندان در زيركروه هاى زن و مرد تفاوت معنادار ندارد و نيز نتيجه آزمون اسـييرمن نشـان داد كه بين وضعيت سلامت و سـطح تحصـيلات افـراد مشـاركت كنتــه در مطالعـه وجـود ارتبـاط معنـادارى نــارد (p=0.83). همجنين به منظور تعيين ارتباط بين متغيرهاى وضـعيت تاهـل، شغل و وضعيت درآمد با وضعيت سـلامت سـالمندان، از آزمـون تحليل واريـانس يكطرفـه اسـتفاده شـــ نتـايج نشـان داد كـهـ ميانخين امتياز وضعيت سلامت سالمندان در سـطوح متغيرهـاى مذكور تفاوت معنى دار ندارند(جدول شماره ऍ). نتايج ارزيابى هاى مربوط به تامين مفروضه هاى انجام تحليـل ركرسيون קندگَانه نشان داد كه مقادير هـولخى و كشـيدگى در

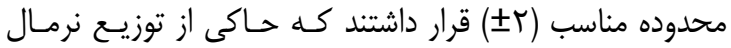

عمومى در اين ثروهش يرسش نامه سلامت عمـومى كلـدبرى بود. يرسش نامه سلامت عمومى از عا خرده آزمون تشكيل شده است كه هر كدام از آنها داراى V سوال مى باشد. سوال هاى هر خرده آزمون به ترتيب قֶت سر هم آمده است. به نحوى كهـ از سوال اتا V مربوط به خـرده آزمـون نشـانه هـاى جسـمانى، از سوال ^ متأ أل مربوط به خرده آزمون اضطراب و بى خـوابى، از سوال ها تا الب مربـوط بـهـ خـرده آزمـون اخـتالال در كـاركرد اجتماعى و از سوال كب تا شT مربوط به خرده آزمـون افسـردىى مى باشد. تمام كويه هاى برسش نامه سلامت عمومى داراى ع كزينه هستند. شيوه نمره كذارى ليكرت است كه بر اساس ايـن شيوه نمره كذارى هر يك از سوال هاى ثٔ درجه اى آزمـون بـهـ صورت(س، ז،1، ) مى باشد و در نتيجه نمره كل يك فرد از • تـا א N متغير خواهد بود و حداكثر نمره در هر حيطه آ است. نمره

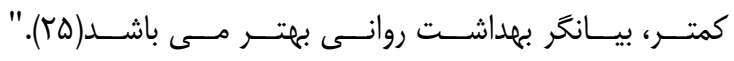
روايى و يايايى برسش نامه عزت نفـس روزنبـرى در مطالـات مختلف فارسى تاييد شــه اسـت. شهمباززادكان و همكـاران در مطالعه خود روى سالمندان پايايى اين ابزار را از طريـق آزمـون مجدد تعيين كرده و ضريب همبستخى آن بـين ك نوبـت هـ/. بدست آمده است(צ؟). روايسى و پِايـايى يرسـش نامـه سـلامت عمومى نيز در مطالعات متعددى سنجيده و تاييد شده است؛ بــهـ عنوان مثال تقوى توNץ| ضرايب اعتبار بـاز آزمـيى، تنصـيفى و

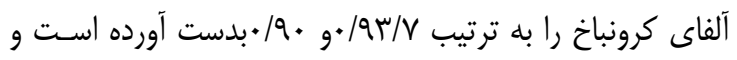
روايى را همزمان با يرسش نامه ميدلكس هه/•و روايى سـازه را

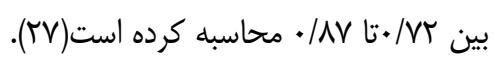
داده ها يس از جمع آورى با استفاده ازنرم افـزار SPSS Vامورد تجزيه و تحليل قرار كَرفت. تحليل بـا اسـتفاده از آمـار توصـيفى و استنباطى(ضـريب همبسـتخى و تحليـل ركرسـيون

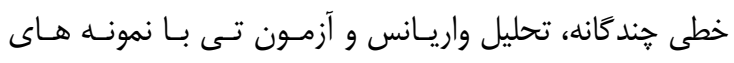


خوبى بر اساس امتيازات متغيرهاى ييش بين مربوطه ييش بينى نمود. در مجموع متغيرهاى وارد شـده در مــل 19/1 درصـد از واريانس كل(R) مربوط به وضعيت سلامت سالمندان را ييش بينى كردند. از بين متغيرهاى ييش بين، دو متغير شـامل عـزت نفس و بسترى در بيمارستان به طور معنادارى وضعيت سـلامت سالمندان را ييش بينى كردند( p<0.001)(جدول p).
متغير بود. همجنين مقادير اغمـاض (tolerance) و VIF در محدوده مناسب قرار داشته و حاكى از عدم وجود هم خطى بين متغيرهاى بيش بين بودند. يافته ها نشان دادند كه مـدل يـيش بينى وضعيت سلامت سالمندان بر اساس متغيرهاى يـيش بـين معنادار بود (F, 239=9.6, p<0.001). اين نتايج بر اين امر دلالت دارند كه امتياز وضعيت سلامت سالمندان را مى توان بـهـ

جدول ( (): توزيع فراوانى و ميانكَين ( انحراف معيار ) ويزَّى هاى فردى و زمينه اي افراد شركت كننده در مطالعه

\begin{tabular}{|c|c|c|}
\hline فراوانى(درصد) & شاخص آمارى & متغير \\
\hline$|\Psi|(\Delta F / \varepsilon)$ & زن & \\
\hline $1.9(f \Delta / f)$ & مرد مرد & جنس \\
\hline $19 \cdot(v 9 / r)$ & متاهل & \\
\hline $\operatorname{FV}(19 / 9)$ & بيوه & تاهل \\
\hline$r(/ \wedge)$ & مطلقه & \\
\hline $19(9 / V)$ & بيكار & \\
\hline$q \cdot(r \vee / \Delta)$ & بازنشسته & \\
\hline$r(/ \Lambda)$ & كارمند & \\
\hline$r(/ \wedge)$ & كارگر & شغل \\
\hline$r r(q / T)$ & آزاد & \\
\hline $1 \cdot \Lambda(F \Delta)$ & خانه دار & \\
\hline $10(8 / T)$ & بدون درآمد & \\
\hline$P \backslash(I V / I)$ & 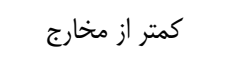 & وضعيت در آمد \\
\hline$M T r(V Q / \Lambda)$ & درحد مخارج & \\
\hline$r(/ \wedge)$ & بيشتر از مخارج & \\
\hline$V \cdot(r q / r)$ & بيسواد & \\
\hline$川(1)(\kappa / \Gamma)$ & ابتدايى و سيكل & \\
\hline 每 & دييلم & سطح تحصيلات \\
\hline$r \varepsilon(1 \cdot / 9)$ & تحصيلات دانشخاهى & \\
\hline ميانخين(انحر اف معيار) & \multicolumn{2}{|c|}{ متغير } \\
\hline$\varepsilon \wedge / \mu q(\mathscr{F} / / F)$ & \multicolumn{2}{|c|}{ سن } \\
\hline $\operatorname{lr}(\mathbf{c} / q \cdot)$ & \multicolumn{2}{|c|}{ ت ت تعداد فرزند } \\
\hline$r(/ \cdot 1)$ & \multicolumn{2}{|c|}{ ماه هاى زندَّى در سراى سالمندان } \\
\hline$G \cdot(\Delta / 9))$ & \multicolumn{2}{|c|}{ روزهاى بسترى شدن در بيمارستان } \\
\hline$r \cdot(r / \Lambda T)$ & \multicolumn{2}{|c|}{ سال هاى ابتلا به بيمارى مزمن } \\
\hline
\end{tabular}


جدول ז:مقايسه ميانكين (انحراف معيار)وضعيت سلامت شركت كنندًان در مطالعه به تفكيك جنس شاخص هاى آمارى

\begin{tabular}{|c|c|c|c|c|c|}
\hline Sig(p.val) & df & $\mathbf{t}$ & ميانتين(انحراف معيار) & متغير & متعير هاى وارد سده \\
\hline$|\Delta F|$ & ה או & $-4 \mid r$ & $19 q / 9 \wedge(1 r / 99)$ & زن & جنس \\
\hline
\end{tabular}

جدول س: مقايسه ميانكين (انحر اف معيار)وضعيت سلامت شر كت كنندكان در مطالعه به تفكيك سطوح متغيرهاى وضعيت تاهل، شغل و وضعيت درآمد

\begin{tabular}{|c|c|c|c|c|c|}
\hline \multicolumn{5}{|c|}{ شاخص هاى آمارى } & \multirow{2}{*}{ متغير هاى وارد شده } \\
\hline \multirow[t]{2}{*}{ Sig(p.val) } & $\mathrm{F}$ & $\mathrm{df}_{1} \mathrm{df}_{2}$ & (انحراف معيار) & ميانغين & \\
\hline & & & $\Delta \cdot / / \Delta(\mid r / F \Delta)$ & متاهل & \multirow{3}{*}{ وضعيت تاهل } \\
\hline \multirow[t]{2}{*}{ / } & \multirow[t]{2}{*}{$1 \wedge 8$} & \multirow[t]{2}{*}{ rera } & $\Delta I / T \Lambda(\mid F / \cdot r)$ & بيوه & \\
\hline & & & gD (Tr/QY) & مطلقه & \\
\hline \multirow{6}{*}{ live } & \multirow{6}{*}{$1 / \Delta \omega$} & \multirow{6}{*}{ orra } & 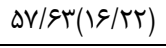 & بيكار & \multirow{6}{*}{ 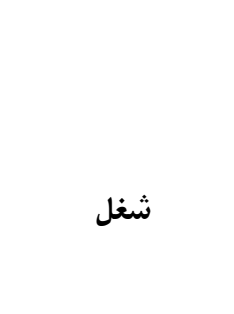 } \\
\hline & & & $\Delta \backslash / \leftarrow \notin\left(1 \Delta / \kappa^{*} \cdot\right)$ & بازنشسته & \\
\hline & & & $01(9 / 9 \cdot)$ & كارمند & \\
\hline & & & $r \& / 0 \cdot(/ V))$ & كارگر & \\
\hline & & & $\Delta I / \Lambda \cdot(I \Delta / R T)$ & آزاد & \\
\hline & & & $\left.\left.\mid F_{N} / F^{+}\right)(1) / T_{\cdot}\right)$ & خانه دار & \\
\hline \multirow{4}{*}{ lQVYF } & \multirow{4}{*}{ I VTV } & \multirow{4}{*}{ erra } & $\Delta \cdot / 9 \cdot(11 /<\varepsilon)$ & بدون درآمد & \multirow{4}{*}{ وضعيت درآمد } \\
\hline & & & $\Delta r / T r(I r / \& V)$ & كمتر از مخارج & \\
\hline & & & {$[q / q \cdot(15 / 91)$} & درحد مخارج & \\
\hline & & & $r q(\cdot)$ & بيشتر از مخارج & \\
\hline
\end{tabular}


جدولع: نتايج حاصل از تجزيه و تحليلر كر سيون جُندكانه براى ارزيابى اثر يِيش بينى كننده متغيرها بر وضعيت سلامت

شاخص هاى آمارى

متغير هاى وارد شده

\begin{tabular}{|c|c|c|c|c|c|}
\hline Sig & $\mathrm{t}$ & Beta & $\begin{array}{l}\text { Std. } \\
\text { Error }\end{array}$ & $B$ & \\
\hline / & IAVq & $1 . \Delta F$ & $/ T \cdot D$ & $M$. & سن \\
\hline IAVT & $-|19|$ & $-1 \cdot 1 \cdot$ & 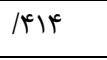 & $-1.9 \mathrm{~V}$ & تعداد فرزند \\
\hline$/ \mu \cdot 1$ & שr./ & 1.91 & $F / D \mid \Lambda$ & r/gr. & زندَّى در سراى \\
\hline $\mathrm{p}<\cdot 1 \ldots 1$ & G/VTr & $/ F \cdot r$ & $111 \mathrm{r}$ & IVQF & بسترى شدن در \\
\hline 1941F & 1.r. & $-1+\cdots 1$ & $\pi .$. & $-1+\cdot c$ & ابتلا به بيمارى مزمن \\
\hline سו.| & T/TqV & ||$Q \mid$ & K. & $10 \cdot 0$ & عزت نفس \\
\hline
\end{tabular}

زى يان و همكاران روى جمعيت 11-- • سـاله نشـان داد كـهـ كسانى كه سلامت روان بالاترى دارند در مقايسه با كسانى كـهـ دجار مشكلات روانى هستند سطح بالاترى از عزت نفس را دارا

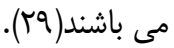
يافته برجسته ديخر اين يثوهش بيانكر ايسن اسـت كـه بسـترى شدن در بيمارستان توان بيش بينى وضعيت سلامت سـالمندان را دارد و بين اين دو متغير ارتبـاط منفـى و معنـادار وجـود دارد. مطالعه رئيسى و همكاران روى سالمندان شهر اصفهان به طـور غير مستقيم ارتباط معكوس و معنـادارى بـين بسـترى شـدن و وضعيت سـامت را حمايـت مسى كنـد. وى در يـرزوهش خـود دريافت كسانى كه سواد سلامت پإيين تـرى دارنـد از وضـعيت سلامت يايين ترى نيز برخوردار مى باشـند و در نتيجـهـ ميـزان بسترى شدن در اين افراد بيشـتر مسى شـود؛ بنـابراين وضـعيت

1.Zi-Yanet al
بحث و نتيجه كَيرى

يافته هاى اين يزوهش كه با هـدف بررسـى و مقايسـه تعيـين كنتده هاى وضعيت سـلامت در سـالمندان مراجعـه كنتـده بــه مراكز سلامت شهر اصفهان انجام شد، حاكى از ايـن اسـت كـهـ مدل بيش بينى وضعيت سلامت سالمندان بر اساس متغيرهـاى ييش بين، معنادار بود و در مجموع متغيرهاى وارد شده در مــل 19/1 درصد از واريانس وضعيت سلامت سالمندان را ييش بينى كردند. از بين متغيرهاى ييش بين، دو متغير شامل عزت نفس و طول مدت بسترى در بيمارسـتان بـهـ طـور معنـادارى وضـعيت سلامت سالمندان را ييش بينى كردند. برخى از مطالعات ييشين نيـز كـهـ بـهـ بررسـى ارتبـاط وضـعيت سلامت با عزت نفس يرداخته انـد، نتـايج مشـابهى را حـزارش نموده اند؛ به عنوان مثال مى توان به مطالعه ربيعى و همكـاران اشاره كرد. نتايج اين مطالعه حاكى از ارتباط مثبت و معنادار ابعاد سلامت، با عزت نفس سالمندان مى باشد(ب)). همجنين مطالعه 
معكوس و معنادار متغير سطح تحصـيلات و سـامت اجتمـاعى است؛ به طورى كه با افزايش ميزان تحصيلات، ميزان سـلامت اجتماعى كاهش مى يابد(اس). در بررسى نقش ييش بينى كننده ديخر مشخصات فردى مطالعه حاضر، عدم رابطه مثبت و معنادار تاهل و وضعيت سلامت سالمندان مى باشد. در مطالعـه نجفى نيـز ارتبـاطى بــين تاهـل و سـلامت روان سـالمندان وجـود نداشت(بآ)؛ اما در مطالعه حيدرى سالمندان متاهل نسـبت بـهـ بقيه گروه ها وضعيت سـلامت بهتـرى داشـتند(سا)؛ همجنـين عليزاده در مطالعه خود از ارتباط مثبت و معنادار تاهل با سلامت جسمانى سالمندان حمايت مى كنــ(Tس). برهـانى نـزاد نيـز در مطالعه خود بيان مى كند كه ميزان استفاده سالمندان متاهـل از خدمات بهداشتى به ويـزه خــدمات سـريايـى بيشـتر اسـت(سب)؛ همجِنين عليزاده در تحقيق خود تاهل را به عنـوان يـيش بينى كننده موثر بر عملكرد فيزيكى و سلامت جسمانى سالمندان مى داند(rس)؛ در حالى كه نتايج يزوهش فرزانه نشان مى دهـــ كـهـ سلامت اجتماعى در افراد بدون همسر بيشتر از سالمندان متاهل است(آ). يافته مهم ديخر عدم توان ييش بين شغل بـا متغيـر ملاك بود. نتايج بروهش نجفى نيز هم راستا با مطالعـه حاضـر مى باشـــ و در پـرثوهش وى نيـز بـين ايـن دو متغيـر ارتبـاط معنادارى وجود ندارد. عدم ارتباط وضعيت اشتغال ممكن اسـت به اين امر مربوط باشـد كـه سـالمندان در جامعـه مـا شـكايت كمترى از وضعيت مالى خود نسبت به بالغين دارنسد(بآ)؛ امـا در مطالعه حيدرى افـراد شـاغل نسـبت بــه افـراد بيكــار وضـعيت سلامت بهترى داشتند(سٓ). همجنين وضعيت درآمد با وضـعيت سلامت سالمندان در ايـن يـزوهش ارتبـاطى نداشـت؛ ولى در مطالعه حيدرى سالمندانى كه وضعيت اقتصادى خـوب و داراى منبع درآمد بودند و سالمندانى كه از شغل فعلى درآمدى داشتند،

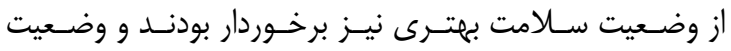

سلامت سالمندان با بسترى شدن آنها ارتبـاط منفىى و معنـادار دارد و مى توان كَفت كه يافته هاى مذكور به نحـوى بـا نتـايج اين مطالعه همخوانى دارد(·"). همجنين يافتـه هـاى يـروهش حاضر در بررسى نقش ييش بينى كننده هر يكى از ويزگى هـاى فردى و زمينه اى سالمندان، ميانخين وضعيت سلامت سالمندان در زيرگروه هاى زن و مرد تفـاوت معنـادار نــارد. يافتـه هـاى مطالعه حيدرى نيز همسو با اين مطالعه مى باشد و ارتباط بـين جنس و وضعيت سلامت وجـود نداشـت؛ ولى نمـره ميـانكين وضعيت سلامت سالمندان مرد بيشتر از زنان بود(سץ)؛ اما يافتـه هاى يروهش نجفـى روى سـالمندان اخـتاف معنـادارى را در سلامت روان سالمندان زن و مرد بدست آورده و اين اختلال در زنان بيشتر بوده و وضعيت سلامت روان در زنان بدتر از مـردان بوده است(آب)؛ همجنين براتى در مطالعه خـود روى سـالمندان دريافت، وضعيت سلامت روان مردان بهتــر از زنـان اسـت كـهـ شايد به دليـل عوامـل سـاختارى جامعــه نقـش و يايخــاه هــاى اجتماعى مردان نسبت به زنان باشد(+(). نتايج تحقيـق فرزانـه نيز نشان مى دهد كه در ميان زنان و مـردان سـالمند از لحـاظ سلامت اجتماعى تفاوت وجود دارد و مردان از سلامت اجتماعى

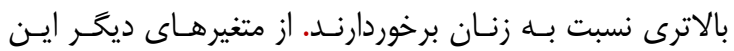
تحقيق، مى توان به سطح تحصيلات اشاره كرد، نتايج نشان داد كه ارتباط معنادارى بين وضعيت سـلامت و سـطح تحصـيلات افراد مشاركت كننده در مطالعه وجود ندارد. يافته هاى مطالعات انجام شده در اين زمينه با هـرَوهش حاضـر همسـو نيســ؛ بـــ عنوان مثـال در مطالعـه حيـدرى، سـطح تحصـيلات ديـيلم و دانشگَاهى با سلامتى ارتباط مثبت و معنادار دارد(1)؛؛ همجنـين نتايج مطالعه نجفى روى جمعيت سالمندان مبنى بر رابطه مثبت و معنــادار سـطح تحصـيلات و وضـعيت سـلامت آنـان مسى باشد(19)؛ در حالى كه يافته هاى يزوهش فرزانه حاكى از ارتباط 


$$
\begin{aligned}
& \text { فرزندان خود زندكى مى كنــــد در انجـام فعاليـت هـاى روزمـره } \\
& \text { اقتصادى از عوامل تاثير كذار بر سلامت سـالمندان بـود(ب؟). در } \\
& \text { زندگى خود مستقل تر و سلامت جسمانى بالاترى دارند(؟؟). } \\
& \text { حالى كه يافته هاى يزوهش فرزانـه بيـانكر ارتبـاط معكـوس و } \\
& \text { البته محدوديت هاى يزوهش مى توانــ در تفسـير نتـايج مـوثر } \\
& \text { معنادار درآمد با سلامت اجتماعى بود و به عبارت ديخـر هرجهـهـ. } \\
& \text { باشد. كم بودن حجم نمونــ؛ عـدم برداشـت صـحيح سـوالات } \\
& \text { ميـزان درآمــــــــد بيشـتر باشــ، سـلامت اجتمـاعى او كمتـر } \\
& \text { يرسش نامه ها توسط آزمودنى ها عليرغم حضـور يزوهشــَر، از } \\
& \text { محدوديت هاى اين بزوهش بود. } \\
& \text { ييشنهادات } \\
& \text { بر اساس نتايج مطالعه و با توجه به نقش تعيين كننده متغيرهاى } \\
& \text { يزوهش(عزت نفس و بسترى شدن در بيمارستان) بـر وضـعيت } \\
& \text { سلامت مددجويان سالمند، توجه به تمركز دادن منـابع حمـايتى } \\
& \text { به سمت افزايش رفتارهاى ارتقا دهنده عـزت نفس مـددجويان } \\
& \text { سالمند توصـيه مسى شـود. همجنــين افـزايش آكَاهى مراقبـان } \\
& \text { بهداشتى و خانواده ها و اطرافيان آنها نسبت بـه درك سـلامتى لـ } \\
& \text { سالمندان به منظـور حفـظ و ارتقـاى سـلامت در همــه ابعـادو و } \\
& \text { كاهش ميزان بسترى شدن ايشان ييشنهاد مى كردد. }
\end{aligned}
$$

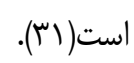

$$
\begin{aligned}
& \text { از ديكر نتايج اين مطالعه مى توان اشاره كرد كه سـابقه زنـدكى } \\
& \text { در سراى سالمندان و ابتلا به بيمارى مـزمن وضـعيت سـلامت } \\
& \text { سالمندان را ييش بينى نمى كند؛ اما در مطالعه حيــدى افـرادى } \\
& \text { كه به بيمارى مزمن دهار نيستند، نسبت به كسانى كـه بيمارى } \\
& \text { مزمن دارند، از وضعيت سلامت بهترى برخوردار مى باشند(ب)؛ } \\
& \text { عليزاده نيز اختلالات و بيمارى هاى مـزمن رادر سـالمندان بـهـ } \\
& \text { عنوان يكى از ييش بينى كننده هاى سلامت جسمانى سالمندان } \\
& \text { بيان مى كند(Yس)؛ همجنين در مطالعه حاضر تعداد فرزندان نيز } \\
& \text { توان وييش بين وضعيت سلامت را ندارد؛ اما حيـدرى در مطالـهـ } \\
& \text { خود دريافت سالمندانى كه با همسر و فرزندانشـان زنـــى مسى } \\
& \text { كردند نسبت بـــ كَروه هـاى ديخـر وضـعيت سـلامت بهتـرى }
\end{aligned}
$$

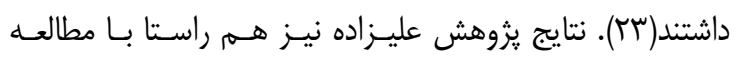

$$
\begin{aligned}
& \text { حيدرى است و در مطالعه وى نيـز سـالمندانى كـه بــا همســر و }
\end{aligned}
$$

\section{- References}

1. Abedi H, Alavi H, Aseman rafat M, azdani M. Nurses elderly patients relationship experiences in hospital wards- a qualitative study. Nursing \& Midwifery Researches. 2005;29:5-14.

2. Choi K, Jang S, Lee M, Kim K. Sexual life and self-esteem in married elderly. Archives of Gerontology and Geriatrics. 2011;53(1):17-20. 
3. de Belvis AG, Avolio M, Spagnolo A, Damiani G, Sicuro L, Cicchetti A, et al. Factors associated with health-related quality of life: the role of social relationships among the elderly in an Italian region. Public Health. 2008;122(8):784-93.

4. Payahoo L, Khaje-bishak Y, Pourghasem B, Asghari jafarabadi M, Kabir-alavi M. The survey of the relationship between quality of life of elderly with depression and physical activity in Tabriz, Iran. journal of Rehabilitition. 2013;2(2):39-46.

5. Koochaki g, Hojjati h, Sanagoo a. The Relationship between Loneliness and Life Satisfaction ofthe Elderly in Gorgan and Gonbad Cities. Journal of Gorgan Bouyeh Faculty of Nursing \& Midwifery. 2012;9(1):61-8.

6. Yazdanian A, Alavi M, Irajpour A , Keshvari M. Association between nurses' personality characteristics and their attitude toward the older adults. Iranian Journal of Nursing and Midwifery Research. 2016;21(1):9-13.

7. Stevens LA, Viswanathan G, Weiner DE. Chronic Kidney Disease and End-Stage Renal Disease in the Elderly Population: Current Prevalence, Future Projections, and Clinical Significance. Advances in Chronic Kidney Disease. 2010;17(4):293-301.

8. Ghazavi Z, Feshangchi S, Alavi M , Keshvari M. Effect of a Family-Oriented Communication Skills Training Program on Depression, Anxiety, and Stress in Older Adults: A Randomized Clinical Trial. Nurs Midwifery Stud. 2016;5(1):1-8.

9. Mokhtari F, Ghasemi N. Comparison of Elderlys "Quality of life and mental health living in nursing homes and members of retiered club of Shiraz city" Iranian Journal of Ageing. 2011;5(18):53-63.

10. Barati M, Fathi Y, Soltanian A, Moeini B. Mental Health Condition and Health Promoting Behaviors among Elders in Hamadan. Scientific Journal of Hamadan Nursing \& Midwifery Faculty. 2012;20(3):12-22.

11. Cheng J, Nayar M. A review of heart failure management in the elderly population. The American Journal of Geriatric Pharmacotherapy. 2009;7(5):233-49.

12. Molavi R, Alavi M, Keshvari M. Relationship between general health of older health service users and their self-esteem in Isfahan in 2014. Iranian Journal of Nursing and Midwifery Research. 2015;20(6):717-22.

13. Shakerinia I. Effect of Social Assists and Hopefulness in Elderly Health Status with Chronic Pain. Iranian Journal of Ageing. 2012;7(24):7-15. 
14. Alavi M, Abedi H, Tavakkol K, Fanian N, Karimi M, Yazdani M, et al. Nurses and older patients' experiences about communication approaches between nurses and older patients. Nursing \& Midwifery Researches. 2006;33:7-17.

15. Okamoto K, Harasawa Y, Momose Y, Sakuma K. Risk factors for 6-year mortality by gender in a Japanese elderly population. Archives of Gerontology and Geriatrics. 2007;45(3):335-41.

16. Matthews SJ, Lancaster JW. Urinary Tract Infections in the Elderly Population. The American Journal of Geriatric Pharmacotherapy. 2011;9(5):286-309.

17. King Jr, Lichenstein R, Magder LS. Relationship of influenza vaccine match and use rate to medically attended acute respiratory illnesses in older residents of Maryland. November 13, 2012. Vaccine. 2013;31(5):839-44.

18. Tse W, Libow LS, Neufeld R, Lesser G, Frank J, Dolan S, et al. Prevalence of movement disorders in an elderly nursing home population. Archives of Gerontology and Geriatrics. 2008;46(3):359-66.

19. Chau PH, Wong M, Woo J. Challenge to Long Term Care for the Elderly: Cold Weather Impacts Institutional Population More than Community-Dwelling Population. Journal of the American Medical Directors Association. 2012;13(9):788-93.

20. Deepthi R, Kasthuri A. Validation of the use of self-reported hearing loss and the Hearing Handicap Inventory for elderly among rural Indian elderly population. Archives of Gerontology and Geriatrics. 2012;55(3):762-7.

21. Alipour F, Sajadi H, Forouzan A, Nabavi H, Khedmati E. The role of social support in the anxiety and depression of elderly. Iranian Journal of Ageing. 2008;4(11):53-61.

22. Golparvar M, Bozorgmehri K, Kazemi M. Integrative relationship between retirement syndromes components with general health symptoms among retired adults. Iranian Journal of Ageing. 2011;6(20):15-25.

23. Heidari S, MohammadGholizadeh L, Asadolahi F, Abedini Z. Evaluation of Health Status of Elderly in Qom City, 2011, Iran Qom Univ Med Sci J 2013. 2013;7(4):71-80.

24. Najafi B, Arzaghi M, Fakhrzadeh H, Sharifi F, Shoaei S, Alizadeh M. Mental health status and related factors in aged population:Urban health equity assessment and response tool (Urban- HEART) study in Tehran ijdld. 2013;13(1):62-73.

25. Taghavi R. The Normalization of General Health Questionnaire for Shiraz University Students (GHQ-28). Daneshvar Raftar. 2008;15(28):1-13. 
26. Shahbazzadegan B, Farmanbar R, Ghanbari A, AtrkarRoshan Z, Adib M. The Effect of Regular Exercise on Self-esteem in Elderly Residents in Nursing Homes. Journal of Ardabil University of Medical Sciences. 2008;8(4):387-93.

27. Ebrahimi A, Molavi H, Moosavi G, Bornamanesh A, Yaghobi M. Psychometric Properties and Factor Structure of General Health Questionnaire 28 (GHQ-28) in Iranian Psychiatric Patients. Journal of Research in Behavioural Sciences. 2007;5(1):5-11.

28. Rabiei 1, Mostafavi F, Masoudi R, Hassanzadeh A. Effects of Family-Centered Interventions on Empowerment of the Elderly. Journal of Health System Research. 2011;8(2):301-13.

29. Zi-Yan Xu, SiZu A, Yu-TaoXiang A, NaWang A, Zhi-HuaGuo A, Amy M,Kilbourne C. Associationsofself-esteem, dysfunctional beliefs and copingstyle with depressionin patients with schizophrenia:Apreliminarysurvey. PsychiatryResearch. 2013;209:340-5.

30. Reisi M, Mostafavi F, Mostafavi F, Hasanzade A, Sharifirad GH. The Relationship between Health Literacy, Health Status and Healthy Behaviors among Elderly in Isfahan, Iran. Journal of Health System Research. 2011;7(4):469-80

31. Farzaneh S, Alizadeh S. Study in Social Determinants on Social Health among Older People in Babol Town. 2013;2(1):183-208.

32. Alizadeh M, Rahimi A, Arshinji M, Sharifi F, Arzaghi M, Fakhrzadeh H. Physical health status and socio-economic outcomes on elderly in Tehran metropolitan area. ijdld(Iranian Journal of Diabetes and Metabolism). 2013;13(1):29-37.

33. Borhaninejad V, NaghibzadehTahami A, Nabavi H, Rashedi V, Yazdi-Feyzabadi V. The utilization of health services and its influences among elderly people in Kerman-2014. Journal of North Khorasan University. 2015;7(2):229-40. 